\title{
Auspicious Management of a Acute Obstructive Left Colon Tumor in a 93-year-old Patient - Case Report and Literature Review
}

\author{
Gabriel Nicolae Andrei', Gabriel Constantinescu ${ }^{1,2}$, Cristian Nedelcu' ${ }^{2}$, Bogdan Cristian Dumitriu ${ }^{1,3}$, \\ Sebastian Valcea', Mircea Beuran ${ }^{1.3}$ \\ 'University of Medicine and Pharmacy "Carol Davila", Bucharest, Romania \\ 2Department of Gastroenterology, Clinical Emergency Hospital Bucharest, Bucharest, Romania \\ ${ }^{3}$ Department of Surgery, Clinical Emergency Hospital Bucharest, Bucharest, Romania
}

Corresponding author: Dr Bogdan Cristian Dumitriu, PhD student Department of General Surgery Emergency Hospital Floreasca street no. 8, Sector 1, Bucharest, Romania E-mail: b_dumitriu@yahoo.com

\section{Rezumat}

Managementul benefic al unei tumori de colon stâng ocluzive la un pacient de 93 de ani - raportare de caz și recenzie a literaturii

Vã prezentãm cazul unui pacient în vârstã de 93 de ani cu ocluzie intestinalã datorate unei tumori de colon descendent, cu ascitã carcinomatoasã şi determinãri secundare hepatice şi pulmonare. Având în vedere riscurile asociate unui act chirurgical la un astfel de bolnav cât şi imposibilitatea efectuãrii unei intervenții curative, a fost montat un stent colonic metalic auto-expandabil. Evoluția post-intervenție a fost favorabilã, pacientul fiind externat 48 de ore mai târziu. Cancerul de colon stâng se diagnosticheazã în fazã ocluzivã în 8 pânã la $26 \%$ din cazuri (1). Acesta, necesitã de cele mai multe ori o rezolvare imediatã chirurgicalã datoritã potențialului risc de deces. Procedurile chirurgicale efectuate în regim de urgențã asociazã rate crescute de morbiditate şi mortalitate (2). Astfel au fost dezvoltate alte modalitãti de rezolvare ale acestor urgențe chirurgicale. Stenturile colonice au fost raportate prima datã în literaturã de cãtre Dohmoto (3). Inițial, folosirea stenturilor a fost gandita ca şi metoda finala de paleație (4). Ulterior sau folosit ca punte catre chirurgia programata minim invaziva (5).

Cuvinte cheie: tumora de colon descendent, ocluzie intestinalã, stent colonic metalic auto-expandabil 


\section{Abstract}

We present the case of a 93-year-old patient with intestinal occlusion due to a descending colon tumor, with carcinomatous ascites and secondary liver and lung determinations. Considering the risks associated with a surgical act in such a patient and the impossibility of performing a curative intervention, a self-expanding metallic colonic stent was mounted. The post-intervention evolution was favorable, the patient being discharged 48 hours later. Left colon cancer is diagnosed in the occlusive phase in 8 to $26 \%$ of cases (1). It often requires an immediate surgical resolution due to the potential risk of death. Emergency surgery involves increased rates of morbidity and mortality (2). Thus, other ways of resolving these surgical emergencies have been developed. Colonic stents were first reported in the literature by Dohmoto (3). Initially, the use of stents was as the final method of palletising (4). Later, they were used as a bridge to minimally invasive programmed surgery (5).

Key words: descending colon tumor, bowel obstruction, self-expanding metallic colonic stent

\section{Introduction}

Colorectal malignant tumors are an important health problem with a total of one million new cases diagnosed worldwide each year and half a million deaths (6). Bowel obstruction is the most frequent acute manifestation of colon cancer, with a reported percentage ranging from $8 \%$ to $26 \%$ (7). In general, left-sided colon cancer tends to obstruct more commenly the colon lumen than the right-sided malignancies because the smaller diameter that they have. The inveterate tratment of the obstructed colon cancer is surgery. Anyhow, the acute obstructed left sided colon tumor has very important medical implications (8) and emergency surgery without a prepared colon has higher rates of morbidity and mortality (9). On the other hand, patient with colonic obstruction have a 5-year survival rate of less than $20 \%$, compared to those without obstruction (10). A total of $60 \%$ of left-sided colonic obstructions secondary to carcinoma need a temporary or permanent colostomy, this having a significant impact on quality of life (11) and up to $20 \%$ of patients have metastatic disease at the time of the diagnosis, thus being poor candidates for surgical resection with curative intent. In the recent time, the use of colonic stents for palliative therapy is growing, furthermore their efficacy and safety has been demonstrated repeatedly, becoming the treatment of choice in this scenario. Another role of the colonic stents, introduced later in practice, is to allow the decompresion of the bowel and prepare the patient for scheduled surgery.

\section{Case Report}

We present the case of a 93-year-old patient who was hospitalized in the surgery department of the Emergency Hospital of Bucharest for diffuse abdominal pain with the maximum of intensity at the level of the periombilical region and left flank, lack of intestinal transit for faeces and gas, symptomatology started 5 days ago which has progressively increased. From personal pathological antecedents, we find that the patient was diagnosed with a sessile polyp located $30 \mathrm{~cm}$ from the anal verge, 6 years previously. At that time the histopathological examination revealed carcinoma in situ. The patient refused the resection at that time. Plain abdominal radiography done at admision revealed hydro-aeric levels (Fig. 1).

The ultrasound showed the presence of tumoral nodules diseminated in both lobes of the liver and and peritoneal fluid in average amount. Immediately after admission, urinary catheter and nasogastric probe have been mounted. Also, it was initiated hydroelectrolytic rebalancing, antialgic, prokinetic and anti- 


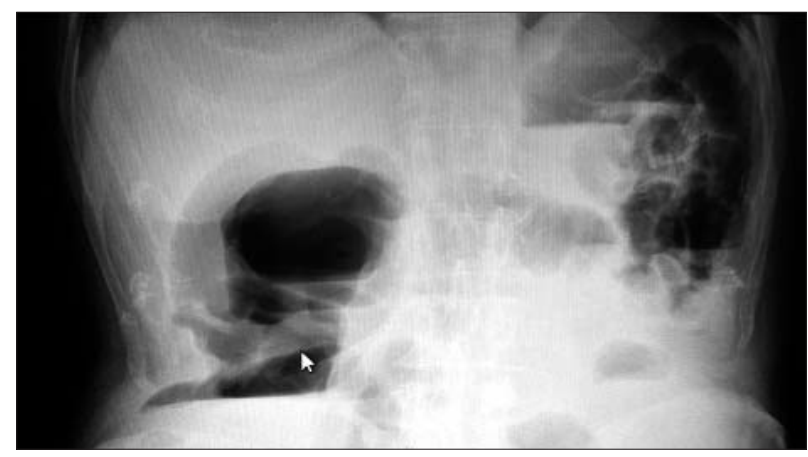

Figure 1. Hydro-aeric levels on plain abdominal radiography

coagulant medication. The patient was then scheduled for thoraco-abdomino-pelvic computed tomography with contrast substance administered orally and intravenously. Tomographic examination showed a 6/6,5/6,2 $\mathrm{cm}$ hepatic tumor located at segments VIII and IV and hypodense areas at segment II and caudal lobe (Fig. 4). Also, important dilatation of the small bowel and colon (Fig. 3) with a sudden transition area at the level of the junction between sigmoid colon and descending one where a parietal thickening is visualized (Fig. 2). Large amount of peritoneal fluid present in all abdominal recesses. Multiple mesenteric adenopathies with dimensions up to $1,3 \mathrm{~cm}$ and retroperitoneal ones.

Taking into account the advanced stage of the neoplastic disease, thus the impossibility of curative surgical resection and the negative impact of such an extensive surgery on the biological balance of the patient, it was considered appropriate mounting a self-expanding metallic colonic stent. After conducting a mechanical preparation of the distal colon through multiple enemas, a rectosigmoidoscopy was performed. The thin endoscope was inserted up to the level of tumor stenosis located $40 \mathrm{~cm}$ from the anal verge (Fig. 5). A guide wire is advanced on a right cannula upstream of the stenosis. Contrast substance is injected, thus visualizing the length of the stenosis - about $3 \mathrm{~cm}$ (Fig. 6). The thin endoscope is then changed with the colonoscope. After that a non-covered expandable metal stent of $10 / 2.2 \mathrm{~cm}$ was inserted (Fig. 7), positioned and expanded under radiological and visual control (Fig. 8). Post-installation, very large amounts of faeces are evacuated. The post-intervention

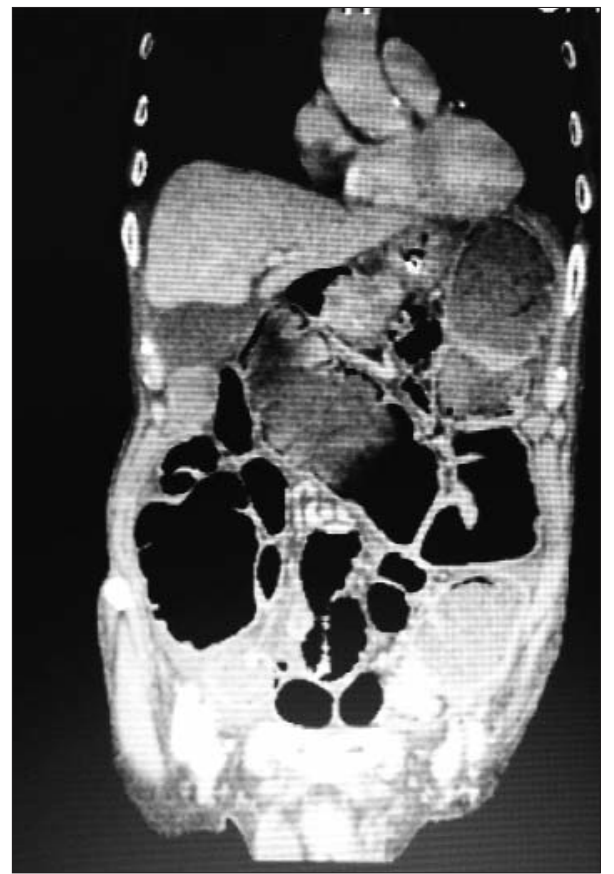

Figure 2. Transition area between sigmoid colon and descending one where a parietal thickening is visualized

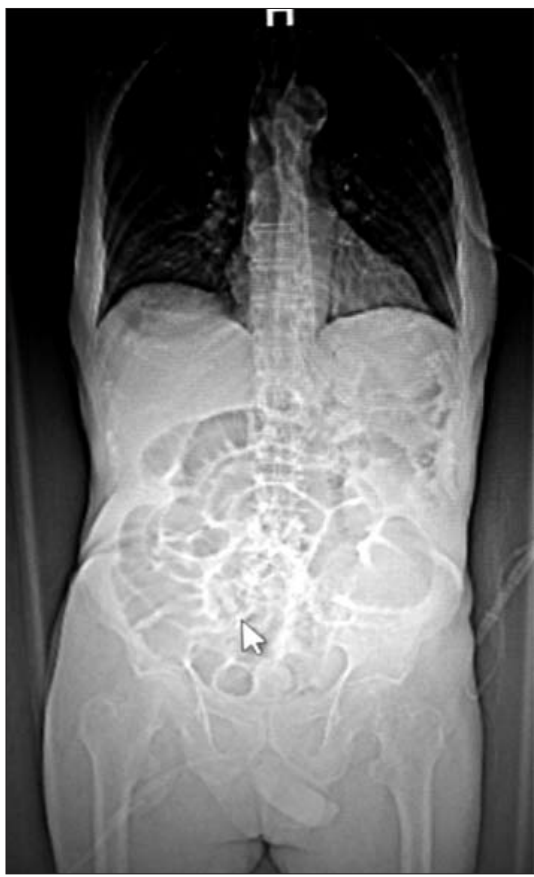

Figure 3. Important dilatation of the small bowel and colon 


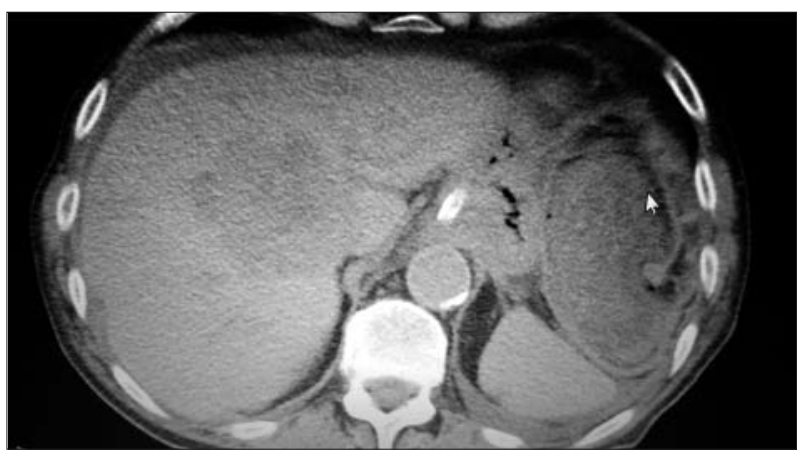

Figure 4. Hepatic tumor located at segments VIII and IV and hypodense areas at segment II and caudal lobe

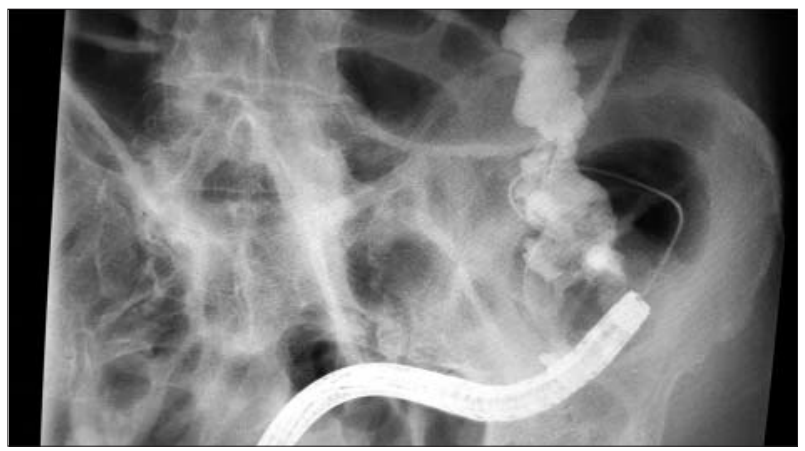

Figure 6. Contrast substance is injected, thus visualizing the length of the stenosis - about $3 \mathrm{~cm}$

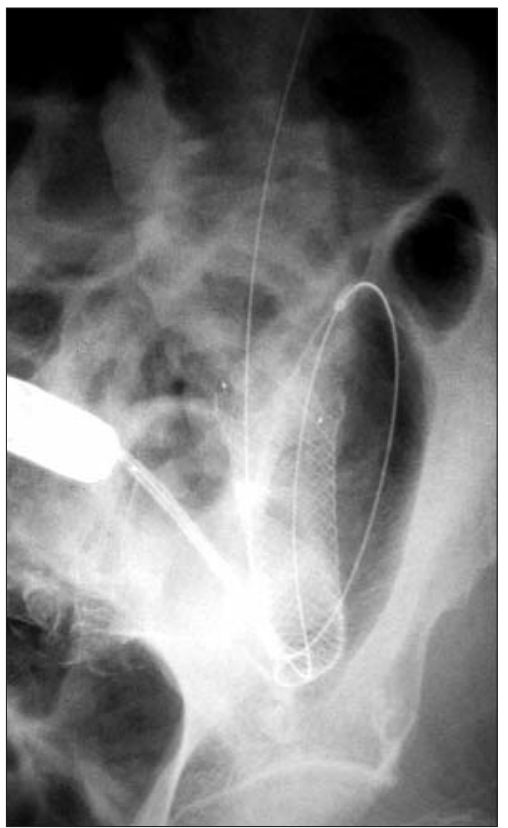

Figure 7. X-ray image showing the colonic stent half-deployed - after it was advanced on the guide-wire that was prior inserted above the stenosis and positioned using fluoroscopic guidance.

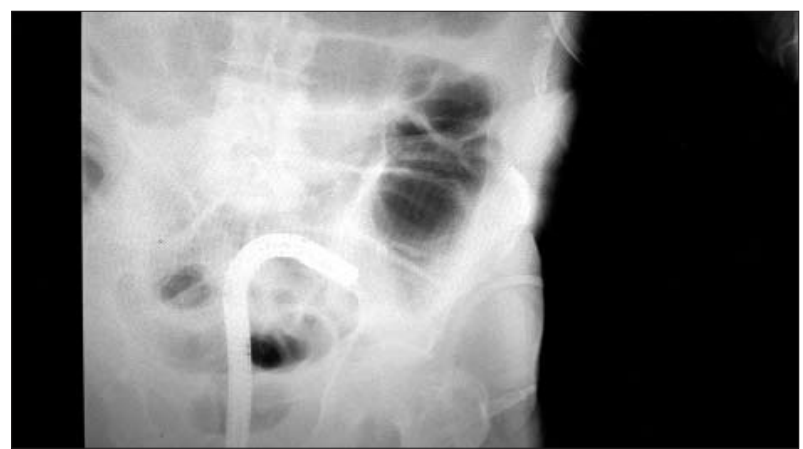

Figure 5. The thin endoscope was inserted up to the level of tumor stenosis located $40 \mathrm{~cm}$ from the anal verge

evolution was favorable, the patient being discharged 48 hours later.

\section{Discussion}

The purpose of stents is to enlarge the diminished or completely stenotic lumen of a segment of the digestive tract. The stents were originally made of plastic material and were used for esophageal cancer. Since the appearance of uncovered self-expanding metal stents in the early 90 s,

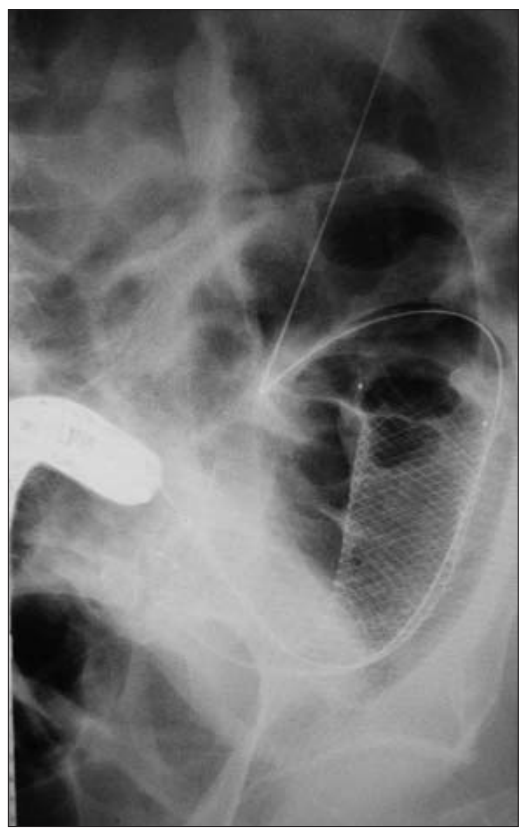

Figure 8. X-ray image showing the colonic stent fullydeployed. The guide-wire was still in place (the $X$-ray was taken before the guide-wire removal). This picture also showes how the middle portion of the stent is narrower due to the tumor compression. Stent patency was afterwards tested by injected 
endoscopic stents have evolved enormous. New designs and materials have determined new indications for the enteral stents. In patients with malignant colonic obstruction, the saving solution in the past was surgical diversion and stoma formation. Endoscopic colonic decompression have less morbidity and mortality and it has been shown to be effective and safe (12). At the moment, colonic stents are considered the main modality for palliative care. Also, there is a permanent development of these stents for various indications. Nowadays, colonic stents are made from a metallic material that is radiopaque with a cylindrical shape and having the ability to self-expand. When they are unexpanded they have a sufficiently small diameter such that they fit into the channel of the endoscope. After it posits in the desired place, they can expand and thus position on the surface of the colon lumen. If the colonoscope can easy pass the obstruction, the stent can migrate more easily after (13). In general, metallic colonic stents can be uncovered, partially covered or fully covered, having a diameter of 20 to $30 \mathrm{~mm}$. Uncovered metallic stents are used more frequently because the risk of migration and perforation is lower. According to the literature, migration rate ranges only between 0 and $2 \%$ (14). Other qualities of the uncovered metallic colon stents are stent rupture and the impossibility of expansion (14). In addition, their use increases the success rate of colonoscopies made after stent-mounted for the diagnosis of synchronous tumors (16) and are much easier to mount. However, there is a higher risk of tumor ingrowth (13).

Contraindications in achieving this method are coagulopathies, perforations, intraperitoneal abscesses or intestinal ischemia (17). Also, mounting stents less than $5 \mathrm{~cm}$ from the anal verge should be avoided due to pain and risk of incontinence (18).

However, in practice the use of stents as a palliative method is associated with a complication risk of up to $25 \%$ (19). These, can be divided into minor and major complications. Minor complications are pain, tenesmus (more frequently in cases with stents below $5 \mathrm{~cm}$ from the anal verge) and mild bleeding.
Usually these are resolved with conservative treatment. Among the major complications the first listed would be stent migration. This occurs in uncovered stents in $36 \%$ of cases. It can be avoided by ensuring a stent positioning of at least $2-4 \mathrm{~cm}$ proximal and distal obstruction in normal tissue (19). The most feared major complication is perforation. Chemotherapy increases the risk of it occurring (20). The most common major complication is stent obstruction due to tumor ingrowth, with a incidence of $10 \%$ (17). This usually happens because colorectal cancers progressively invade local tissues. Options for this complication are surgical treatment or repeat stenting within a stent. Sometimes after the stent is mounted, the colonic decompression may not be possible. This usually occurs to those in whom the stent does not exceed the stenosis area, in cases of synchronous lesions, initial stent migrations or fecal impaction (21).

\section{Conclusion}

Currently colonic stents are the method of choice for treatment in cases of obstructive terminal colorectal cancers. Although colorectal stents are safe with a low incidence of complications, the endoscopist and the surgeon should be familiar with the possibility of them occuring. There is a permanent concern for the development and extension of the stents indications in general.

\section{References}

1. Deans GT, Krukowski ZH, Irwin ST. Malignant obstruction of the left colon. Br J Surg. 1994;81:1270-1276.

2. Lujan HJ, Barbosa G, Zeichen MS, Mata WN, Maciel V, Plasencia G, et al. Self-expanding metallic stents for palliation and as a bridge to minimally invasive surgery in colorectal obstruction. JSLS. 2013; 17(2):204-11. doi: 10.4293/108680813X13654754534990.

3. Dohmoto M. New method-endoscopic implantation of rectal stent in palliative treatment of malignant stenosis. Endosc Dig. 1991; 3:1507-12.

4. Piccinni G, Angrisano A, Testini M, Bonomo GM. Definitive palliation for neoplastic colonic obstruction using enteral stents: personal caseseries with literature review. World J Gastroenterol. 2004;10(5):758-64.

5. Morino M, Bertello A, Garbarini A, Rozzio G, Repici A. Malignant colonic obstruction managed by endoscopic stent decompression followed by laparoscopic resections. Surg Endosc. 2002;16(10): 1483-7. Epub 2002 May 7.

6. Boyle P, Leon ME. Epidemiology of colorectal cancer. Br Med Bull. $2002 ; 64: 1-25$. 
7. Biondo S, Kreisler E, Millan M, Fraccalvieri D, Golda T, Marti Rague, $\mathrm{J}$, et al. Differences in patient postoperative and long-term outcomes between obstructive and perforated colonic cancer. Am J Surg. 2008;195(4):427-32. doi: 10.1016/j.amjsurg.2007.02.027.

8. Griffith RS. Preoperative evaluation. Medical obstacles to surgery. Cancer. 1992;70(5 Suppl):1333-41.

9. Smothers L, Hynan L, Fleming J, Turnage R, Simmang C, Anthony T. Emergency surgery for colon carcinoma. Dis Colon Rectum. 2003;46(1):24-30.

10. Ohman U. Prognosis in patients with obstructing colorectal carcinoma. Am J Surg. 1982;143:742-747.

11. Neugent K, Daniels P, Stewart B, Patankar R, Johnson CD. Quality of life in stoma patients. Dis Colon Rectum. 1999;42(12):1569-74.

12. Shrivastava V, Tariq O, Tiam R, Nyhsen C, Marsh R. Palliation of obstructing malignant colonic lesions using self-expanding metal stents: a single-center experience. Cardiovasc Intervent Radiol. 2008;31(5):931-6. doi: 10.1007/s00270-008-9328-2. Epub 2008 Apr 1.

13. Repici A, de Paula Pessoa Ferreira D. Expandable metal stents for malignant colorectal strictures. Gastrointest Endosc Clin N Am. 2011;21(3):511-33, ix. doi: 10.1016/j.giec.2011.04.005. Epub 2011 May 14

14. Choi JH, Lee YJ, Kim ES, Choi JH, Cho KB, Park KS, et al. Covered self-expandable metal stents are more associated with complications in the management of malignant colorectal obstruction. Surg Endosc. 2013;27(9):3220-7. doi: 10.1007/s00464-013-2897-4. Epub 2013 Mar 14.

15. Park S, Cheon JH, Park JJ, Moon CM, Hong SP, Lee SK, et al.
Comparison of efficacies between stents for malignant colorectal obstruction: a randomized, prospective study. Gastrointest Endosc. 2010;72(2):304-10. doi: 10.1016/j.gie.2010.02.046. Epub 2010 Jun 19.

16. Lim SG, Lee KJ, Suh KW, Oh SY, Kim SS, Yoo JH, et al. Preoperative colonoscopy for detection of synchronous neoplasms after insertion of self-expandable metal stents in occlusive colo-rectal cancer: comparison of covered and uncovered stents. Gut Liver. 2013;7(3):311-6. doi: 10.5009/gnl.2013.7.3.311. Epub 2013 May 13.

17. Baron TH. Colonic stenting: technique, technology, and outcomes for malignant and benign disease. Gastrointest Endosc Clin N Am. 2005;15(4):757-71.

18. Song HY, Kim JH, Kim KR, Shin JH, Kim HC, Yu CS, et al. Malignant rectal obstruction within $5 \mathrm{~cm}$ of the anal verge: is there a role for expandable metallic stent placement? Gastrointest Endosc. 2008; 68(4):713-20. doi: 10.1016/j.gie.2007.12.051. Epub 2008 Jun 17.

19. Sebastian S, Johnston S, Geoghegan T, Torreggiani W, Buckley M. Pooled analysis of the efficacy and safety of self-expanding metal stenting in malignant colorectal obstruction. Am J Gastroenterol. 2004:99(10):2051-7.

20. Rao KV, Beri GD, Wang WW. Trimming of a migrated metal stent for malignant colonic stricture using argon plasma coagulation. World J Gastrointest Endosc. 2010;2(2):75-6. doi: 10.4253/wjge.v2.i2.75.

21. Baron TH, Dean PA, Yates MR, Canon C, Koehler RE. Expandable metal stents for the treatment of colonic obstruction: techniques and outcomes. Gastrointest Endosc. 1998;47(3):277-86. 